\title{
AN AUSTRALIAN ANT OF THE GENUS LEPTOTHORAX MAYR
}

\author{
By William MoRToN WheEleR
}

Leptothorax is supposed to have a cosmopolitan distribution, if we except Australia, Papua and New Zealand, from which no species of this large genus has ever been described. A few species range well up into the north temperate zone, both in North America and Eurasia, while others occur as far south as southern Brazil, the Cape of Good Hope and Sumatra. Several subgenera have been recognized but one is inclined to agree with Emery that the characters on which they are based are rather illusive and unimportant. Furthermore, Leptothorax is not sharply differentiated in tropical America from the genus Macromischa Roger.

It now appears that Leptothorax is represented in the Australian fauna by at least one species. The late Mr. A. M. Lea of Adelaide, South Australia, sent me many years ago a large, miscellaneous collection of ants which he made in various parts of the island continent. Among the specimens, two workers which he took in the Cairns District, Queensland, unquestionably belong to the genus Leptothorax and combine the elongate petiolar peduncle of a group of species (rottenbergi group of Emery), peculiar to the Mediterranean Region, with the epaulate pronotum of the subgenus Goniothorax, to which Emery has assigned the Ethiopian, South African, Malagasy, Sumatran and Neotropical species. Since, however, a similar combination of characters occurs in at least one South African Leptothorax ( $L$. (G.) latinodis Mayr) I am placing the Australian ant in the subgenus Goniothorax.

Leptothorax (Goniothorax) australis sp. nov.

WORKER: Length about $2.7 \mathrm{~mm}$.

Head somewhat longer than broad, broader behind than in front, with short, faintly sinuate posterior border, very 
broadly rounded posterior corners and nearly straight, anteriorly converging sides. Eyes rather large and convex, situated slightly in front of the middle of the head. Mandibles stout, with convex external borders, the masticatory borders with three terminal teeth but with the basal half straight and indistinctly crenulate. Clypeus convex, its anterior border broadly rounded and entire in the middle, sinuate on each side. Frontal carinæ thin, rounded, scarcely diverging behind; frontal area distinct, impressed, elongate; frontal groove absent. Antennæ stout, 12jointed; scapes strongly curved at the base, their tips reaching to slightly more than two-thirds the distance between their insertions and the posterior border of the head; first funicular joint as long as joints 2 and 3 together, 2 nearly as long as broad, 3-8 decidedly broader than long, remaining joints forming a very distinct 3-jointed club, the combined two subequal basal joints of which are shorter than the terminal. Thorax in profile with broadly arcuate dorsal outline, but slightly and indistinctly impressed at the mesoëpinotal suture, broadest through the pronotum; neck large, anterior border of pronotum arcuate, its anterior angles distinct but neither acute nor dentate, its sides straight, parallel and marginate anteriorly, straight and converging posteriorly; promesonotal suture obsolete; mesonotum short, nearly twice as broad as long, with subangulate sides and somewhat flattened dorsal surface; epinotum longer than broad, subrectangular, slightly narrower than the mesonotum, its base from above subhexagonal, with very prominent spiracles, the spines stout and blunt, as long as their distance apart at the base, directed backward and slightly upward and curved inward; the declivity in profile shorter than the base, straight and abrupt above, concave below. Petiole more than twice as long as broad, its peduncle long and stout, as long as the node, with prominent spiracles anteriorly and a sharp anteroventral tooth; the node from above somewhat broader than long, subrectangular, with evenly rounded sides; in profile with concave anterior, straight and horizontal superior and short and convex posterior surface. Post- 
petiole distinctly broader than the petiolar node, roundedtrapezoidal, about one and three-fourths times as broad as long, broader in front than behind, with broadly arcuate anterior border, distinct but blunt anterior angles and straight, rather strongly posteriorly converging sides. Gaster elliptical, with excised anterior border. Femora and tibiæ distinctly incrassated.

Shining, the head, thorax and pedicel less so than the gaster and legs; mandibles very finely punctulate or shagreened, with sparser, indistinct, elongate punctures. Clypeus, head and thorax coarsely and reticulately rugose, the rugæ more longitudinal on the clypeus, front, thoracic dorsum and pleuræ; the interrugal spaces shining and irregularly reticulate; epinotum, petiole and postpetiole finely and regularly reticulate or densely punctate, the petioiar node also irregularly longitudinally rugose, but less sharply than the head and thorax. Gaster and legs smooth and shining, with sparse piligerous punctures; antennal scapes finely punctulate.

Hairs pale yellowish; those on the head, antennal scapes, thorax and abdomen rather abundant, regularly arranged, erect and clavate; those on the legs short, sparse, pointed and appressed.

Brown; head posteriorly and gaster, except anteriorly and posteriorly, darker, castaneous; mandibles, clypeus, bases and borders of posterior gastric segments, antennæ and legs, including the coxæ, brownish yellow or yellowish brown.

Two specimens taken by A. M. Lea in the Cairns District, Queensland. 

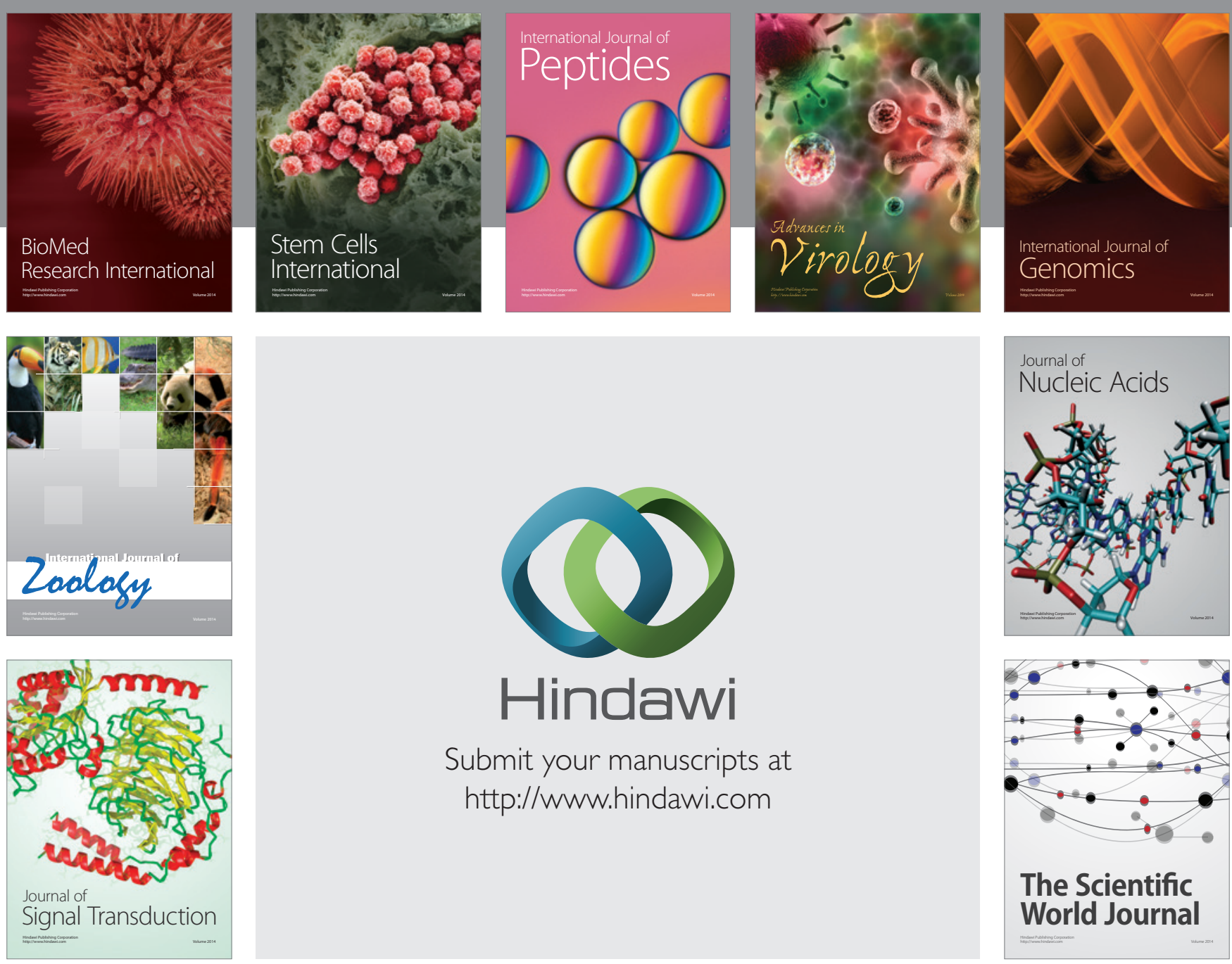

Submit your manuscripts at

http://www.hindawi.com
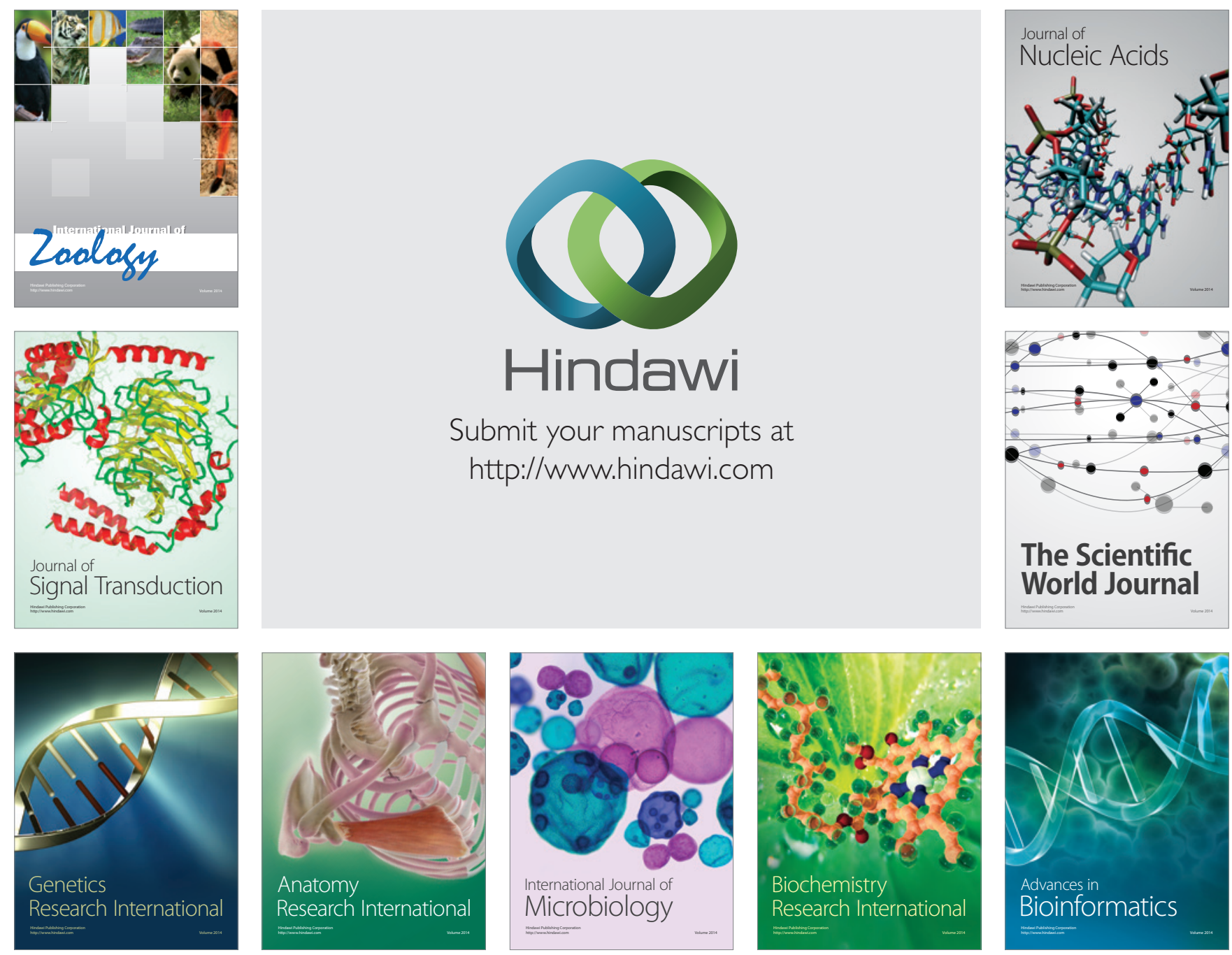

The Scientific World Journal
